\title{
A THRONe FOR THE PeOPLE: OBSERVATIONS ON THE JUMENENGEN OF SULTAN HAMENGKU BUWONO X
}

\author{
Felicia Hughes-Freeland
}

\section{Jogyakarta, March 7, 1989}

There had been extradordinary activity in and around the palace of Ngayogyakarta Hadiningrat since early morning. By 8:30 A.M. people were crowding the railings in front of the palace and along the road running though the center of the North Square where the distinctively somber Bugis brigade of the palace guard was marching slowly back to the palace. By 9:15 A.M. the numbers had increased, constantly shifting in search of better vantage points. At regular intervals around the square, small clusters had formed around television monitors set up by Mitsubishi, a sponsor of the ceremony, to allow the public to see what was going on inside.

As the stately procession of guards, royalty, and retainers moved slowly though the courtyards to the Sitihinggil where the central rituals would occur, the crowd round the monitor became agitated. "Move over, we can't see" -jostling to get a better view- "Get that umbrella down!" The monitor was obscured by a large black umbrella, but its owner refused to budge. Someone grabbed it and pushed it aside, and the screen immediately caught the light, which spoiled the picture. The crowd persisted, reveling in the pushing and shoving that was their personal participation in the event in progress some $900 \mathrm{~m}$ away. A student wearing the purple beret and fatigues of the university brigade stood by, one of the many security personnel brought in for the day. At 9:45 A.M. exactly, the screen showed the Star of Office being pinned on the chest of the new sultan, and the archaic tones of Kangjeng Kyai Guntur Laut rang out. I discovered razor slashes through my bag; thieves were making the most of the hurly-burly, and I withdrew to a safer spot to observe the remainder of the activities.

This article is based on events that took place during a visit to Yogya and a period of research between February and December 1989. The project was funded by the Evans Trust, Cambridge University. My thanks go also to LIPI for supporting my ongoing research into the Javanese performing arts. 
Although this article is about the accession, the media, both printed and broadcast, played a crucial role in determining impressions and opinions about this particular moment in history by providing the frames of reference through which some sense could be made of something that was all too vulnerable to charges of anachronistic irrelevance. Direct experience of the actual ritual was limited to the press and VIPs. Four thousand people were assembled in the palace, but aside from the privileged, which included Governor of Yogya Sri Pakualam, Crown Prince of Solo, Mangkunagoro IX, members of Cirebon palaces, and a number of foreign ambassadors and local businessmen, everyone else had to rely on closed circuit television. It was only during the kirab, the ritual circling of the palace by the sultan on the day after his accession, that the public witnessed in person part of the ceremonies. Even those rituals viewed on television would have appeared little different, perhaps, from the regular palace rituals, such as the Garebags, or the increasingly numerous processions that occur in Yogya as in all Indonesian towns today to celebrate significant anniversaries (such as Indonesian Independence Day) and to stimulate and show national culture had it not been for the frames of reference provided by the media, which served to limit the potential range of perception.

The element of show in the modern manifestations of traditional culture, particularly palace culture, makes it de rigeur for Indonesian intellectuals to allude to Geertz's notion of the theater state when discussing it. ${ }^{1}$ This reaction is inevitable, perhaps, despite major political differences stemming from the fact that the concept was developed with reference to precolonial kingdoms. The historian Onghokham viewed the events in Yogya as theater-a means by which palace institutions could be acculturated to the people. This perception overlooks the interesting aspects of the accession, which bear less on show and the acculturation of palace institutions and the power and legitimacy of an individual than on arguments about local and national identity, interpretations of history, and the definition of cultural and political spheres in oppositional terms. The accession of Sultan Hamengku Buwono $X$ ( $\mathrm{HB} \mathrm{X}$ ) had to be made significant and relevant by casting traditional qulaities in terms of modern values, and the costumed scenes were not an end in themselves but the means to trigger arguments that could make sense of the accession in New Order Indonesia. Tradition is an ideological term that describes not the precise enactment of precedented and established rites and formalities but the overall manner, feel, and style of the event, helped by a number of traditionalizing strategies. The media's role in the events was to represent to the public an acceptable form of tradition for the future.

\section{The King Is Dead: Long Live the King!}

To understand the accession of $\mathrm{HB} X$ it is necessary to review the funeral of HB IX. The ninth sultan died unexpectedly in Washington, D.C. on October 3, 1988 (West Indonesian time), precipitating a phase of mass mourning and anxiety in Yogyakarta. Filmed documentaries show the white carriage bearing the coffin passing through streets thronged with people; tears were running down their cheeks. Once the tears dried, the question of the succession, implicit in the demise of HB IX, became urgent.

The necessity of dealing with the fate of the succession and thus with the special status enjoyed by Yogya since before Independence had been hanging over people's heads since the submission of the sultan to the Republic of Indonesia in clause 18 of the 1945 proclamation. In the early 1980s, gossip and speculation intensified owing to the sultan's unpopular

${ }^{1}$ C. Geertz, Negara (Princeton, N.J.: Princeton University Press, 1981); Onghokham, "Jumenengan" Tempo, March 18,1989, p. 36 . 
marriage to a a non-Javanese woman. His decision not to appoint any one of his four previous secondary wives (garwa ampeyan) as queen (permaisuri) was read by many as a clear indication of his reluctance to establish a succession and a genuine obstruction to the naming of a legitimate heir. Yogya's status as a "special" province rested not on HB IX's traditional position but on his participation in the struggle for independence. For this, he was made governor of his former kingdom while other princes saw their territories incorporated into larger provinces and their authority restricted to their palaces. When HB IX died, it was as a democratic figure, revolutionary leader, "father of sports and scouts" that he was mourned. The significance of his accession on March 18, 1940, had been superseded by the part he played in making possible the ceremonial swearing in of Sukarno as president of the Republic on December 17, 1949, in the same place where he and his son, forty-nine years later, were inaugurated.

It was not the first time that the status of Javanese dynasties had come into question since independence. The death of Mangkunagoro VIII (MN VIII) in Surakarta in September 1987 threatened to strike at the heart of an institution with which the Javanese have been identifying themselves (through proximity or distance) for more than two hundred years. Indeed, the governor of Central Java's strong objection to MN VIII awarding titles to Mayor Hartomo of Surakarta, Bupati Hartono of Karanganyar, and Bupati Oemarsono of Wonogiri (previous territories of the $\mathrm{MN}$ ) is believed by many to have hastened the demise of the $\mathrm{MN}$. The "accession" of his eldest surviving son, Kanjeng Gusti Pangeron Haryo (KGPH) Sudjiwo Kusumo, in January 1988 took place amid an atmosphere of frantic press coverage and furious family rows. ${ }^{2}$ Contention centered on whether or not the new $\mathrm{MN}$ should use the number "IX" after his title, and although he seemed content to assume a purely cultural and artistic role, ${ }^{3}$ the family had not yet reached consensus on matters of title and responsibility.

Like Mangkunagoro IX, HB IX's eldest son had not been appointed crown prince, and unlike the Mangkunagoro, his mother had not been the queen. His appointment in 1974 as Gusti Pangeran Haryo Mangkubumi had given him precedence over his siblings, and in the collection of writings in honor of HB IX, Tahta Untuk Rakyat in 1982, a photograph of Mangkubumi appeared with the caption "the apprenticeship of $\mathrm{HB} X$ has already been prepared." Ironically, this volume revealed that HB IX himself had not been installed as crown prince before his father died in 1939, although he had been presented with a keris, Kyai Jaka Piturun, by his father who had summoned him back to Java from Holland. The thunder that broke when the prince arrived back in Yogya with his ailing father became a local legend, a sign of the cosmic approval of Dorojatun taking his place on the throne. Like his son after him, HB IX went through two accessions at one ceremony, becoming sultan five minutes after being declared crown prince. He underwent a further accession in Jakarta in August 1942, when the commander general of Japan proclaimed him sultan. ${ }^{4}$

After the death of HB IX, the lack of clear signs for succession in both the Kraton and the Mangkunagaran were seen as problematic, although historically the course of accessions in Java never had run smooth. Problems, conflicts, and wars are more often the background to accessions than ordered inevitability, although the traditional approach is to refer to order,

2 See Tempo, January 23, 1988, p. 26, and January 30, 1988, pp. 22-26.

3 Interview conducted by Felicia Hughes-Freeland with KGPA Mangkunagoro IX and R. Ay. Hilmiyah Darmawan Pontjowolo in the Mangkunagaran Surakarta, on April 14, 1989.

${ }^{4}$ Mohamad Roem Mochtar Lubis, Kustiniyati Mochtar, and S. Maimoen, eds., Tahta Untuk Rakyat (Jakarta: Gramedia Press, 1982), p. 59. This text became the unofficial "official" source during HB X's accession and provided examples of how a modern sultan can be represented in print: a modern chronicle, motivated, some suggested, by the need to enhance HB IX's image after his last unpopular marriage. 
precedence, and inevitability, and accounts of takovers are usually carefully processed in subsequent accounts so that everything will fit. Javanese kings have come to the throne more often by illegitimate means than by direct succession; because of this, the discourse of legitimacy has become more important than mere facts. ${ }^{5}$ Despite the post facto incorporation of HB IX into the fixed fates of legendary history, the months of argument with Lucian Adam, governor of Yogya, that led up to his own accession must have fostered speculation about the establishment of the succession. In the end, the aspiring sultan did sign along with Adam, Patih Danurejo, and Abenhuis, the assistant resident; all that remained was the ceremonial attestation to these signatures.

Coronations are critical times of transition-times for the evaluation and definition of order and control. In this sense, then, HB X's accession was quite traditional but with completely different stakes. For this reason, it had become necessary to reinvent the person of the sultan, and there was at times complete bewilderment about how to play the king-making game, particularly during the existence of the big king, the president of the Republic. Colonial accessions had been the results of contracts with the Dutch. Mangkubumi succeeded his father through private family consultations and the personal ratification of Suharto along with a state agreement that Sri Pakualam should become governor of Yogya. Suharto and his generals had attended the funeral of HB IX in force, as befitted a hero, but none were present at the accession of HB X; any ministers who attended did so in a personal capacity. Suharto himself was conveniently occupied by the Panca Wali Krama, rites of purification that take place every twelve years or so at Besakih, the mother temple of Bali. This spared the organizers of the accession horrendous problems of protocol as well as the rupture of the plausible accession image that was well on the way to completion.

The decisions behind closed doors at the sultan's palace and the state palace eliminated a number of problems. HB IX's ability to override the terms of his legitimacy as sultan had made it a real problem to justify his son's continuation of the line without the sanction of having been a hero. HB IX had been a hero of the Old Order, and although he was buried as one by the rulers of a new order, there had been scepticism in Yogya about his agreement to the succession: under the Old Order he was said to have reneged on future accessions, thereby enhancing his status as a hero of the Republic. By the time the accession festivities were over, however, HB X had become a hero of sorts-or had acquired a very high profile indeed. How this happened, and how obstacles were avoided, is related next.

\section{Preparations, Pilgrimages, and Rites of Reportage}

Official ritual for the accession started on March 1, but the kraton staff and the press were already absorbed by the coming events in February. A special column had already been introduced in the main local paper 6 to allow a running commentary on preparations and anecdotes in addition to the in-depth coverage of definable events in the build-up. Definable events included such episodes as the offerings and removal of Mangkubumi and his family from the house near the sugar factory, Madukismo, where he had been manager, to the West Palace (Kraton Kilen). The press provided ongoing reports of the progress of the decorations and the tiling of the bathroom.

\footnotetext{
5 The best-known analysis of the ramifications of Javanese history writing and dynasty defining is in Merle Ricklefs, Yogyakarta under Sultan Mangkubumi 1749-1792 (London: Oxford University Press, 1974).

${ }^{6}$ Kedaulatan Rakyat (Sovereignty of the people) (hereafter cited as $K R$ ), the first Indonesian newspaper to be founded after 1945 and the source of the reports in this article unless otherwise stated.
} 
The private details of the future sultan's domestic arrangements were matched by dayto-day stories about the collection of items necessary for the ritual at the accession. The more bizarre the event, the more extensive was the coverage, as in the search for seventeen abdidalem polowijo, special retainers who are albinos or dwarfs, whose strangeness strengthens the power of the sultan, but who are no longer kept in the palace. The quest of the responsible official took him to advertising companies that had used albinos in their recent commercials, Jamu Jago medicine and Batu Battery ABC; he had more success with Teh Poci, and the full contingent was ready for the rehearsal. ${ }^{7}$

The most noticeable trend in reportage at this stage was the casting of Mangkubumi as the man who was to have been sultan all along. Two themes were used: how he was named and his special tutelage. The story of how he was given his "small" name, Herjuno Darpito, is as follows: HB I had made five wayang figures (shadow puppets) that became palace heirlooms. He predicted that these exquisitely fine figures would be lost during the reign of $\mathrm{HB}$ III and would return during the reigns of HB VIII and HB IX. Once the five were returned, the kingdom would become prosperous again. The five puppets did disappear, and two were retrieved in HB VIII's reign. Javanese heirlooms habitually disappear and return of their own accord.

Not long after his accession, a Chinese came from Cirebon to return something to the kraton. It was the Arjuna figure. So three of the puppets had come back.

Some time before the birth of HB IX's first son, a man came from Ambarawa (a village to the west of Yogya, where HB I had been based bfore he moved into the kraton in Yogya) and handed over the puppet Srikandhi, wife of Arjuna. The area had just been devastated by the Dutch, he said, and the only house to survive was the one where the puppet had been. He requested that the child soon to be born should be called Arjunawiwaha, which means "the accession of Arjuna," but HB DX did not want to call his child by this name and looked for something close. He chose Herjuno Darpito. So four puppets are back and only one remains to be found. 8

This story is one of many prophecies associated with the mystical power of the ruler and is also one of a corpus of legends about HB I's own remarkable powers. No source is given, and the other puppets are not described. What is interesting is the way in which the story has been used to incorporate the future tenth sultan into a long-standing prophecy presaging a golden age for Yogyakarta that seems imminent. By being named for Arjuna, the prince was also endowed with a set of attributes valued by the Javanese. Arjuna has a number of qualites, including a rakish womanizing side, but the quality brought out in the preaccession promotion was that of Arjuna the ascetic, visiting sages and meditating on the mountain. In view of the modern appearance and style of Mangkubumi, it was surprising to read that he had had a special relationship with a mentor selected by HB IX to guide his eldest son. And yet, it is no coincidence that Ki Juru Permono, a puppeteer who still performs purification rites, is from Sleman, the district of Yogya closest to the Merapi volcano. Not only was the future sultan's childhood name a version of Arjuna but he used to seek advice and wisdom from a sage on the mountain.

On Pon Wednesday and Wage Thursday, Rejeb 23 and 24 (March 1 and 2), the first official rituals for the accession were pilgrimages of Mangkubumi, his wife, siblings and their

${ }^{7}$ KR, March 2, 1989.

8 This story originally appeared in Tahta Untuk Rakya, Lubis, Mochtar, and Maimoen, chap. 13, pp. 111-13, as told by HB IX to Kustiniyati Mochtar. The source was very popular with the press in Yogya in 1989. 
spouses, and HB IX's wives, siblings, and affines to the tombs of the ancestors of the line of Mataram-to Kotagede, where Senopati is buried, and Imogiri, where the tombs of Sultan Agung and most subsequent rulers of Surakarta and Yogya are located. The rites of sowan ngintun, (visit and send [flowers]) are carried out regularly by Javanese in the month before fasting or, if wished, on any eve of Kliwon Friday. Such offerings play an important role in defining identity by providing a communicative link beween the deceased and the living. The royal ziarah (pilgrimages) to the ancestral graves at Kotagede and Imogiri were typical validatory actions cast in a maximally ceremonial style befitting the ancestors' status as well as that of the living. Traditional taboos on visits to the royal tombs by living sultans meant that this would be Mangkubumi's final opportunity to pay his respects to his father and ancestors.

If the pilgrimages to the tombs endorsed the place of the sultan in the temporal sphere, spatial cosmological affirmations were also to play a vital part. Certain events outside the officially designated rites are relevant here. In February, presentations were made from the palace to the Sleman and Gunungkidul regions. The presentations consisted of heirlooms: lances, ceremonial parasols, and banyan trees as tokens of the palace's gratitude for help granted. The delegation to Gunungkidul led by Prince Prabukusumo and Ki Juru Permono gave the parasol, pusaka kraton payung agung, to protect the people and to help them overcome their problems, and the lance, Tombak Udan Arum, to bring rain to their very dry region. The presentations were received by the Bupati in each case. ${ }^{9}$

Mangkubumi himself visited Gunungkidul on March 3, 1989, for the ritual washing of three statues that represent heroes who founded the Mataram dynasty: Panembahan Senopati, the first king; Ki Ageng Jurumertani, his foster father; and Ki Ageng Mataram, his advisor and king maker. The statues are located at Banglampir, on Mount Mahenoko, Blimbing, Panggang, a site where Senopati is believed to have heard the "whisper" (wisik) that told him he would be king. Nearby is the place where Ki Ageng Giring received the wahyu, or mystical grace called Wahyu Gono, or Wahyu Si Gagak Emprit Mentaok, betokening the founding of a ruling line. The statues themselves were established in August 1981, a contemporary response to the legend and folklore surrounding the kings of Java and a further recognition of the power of a place. ${ }^{10}$ They are believed to be "full of magic" and were made to express thanks to HB IX's guardians (pamong) in the Gunungkidul region. ${ }^{11}$

Despite the modern qualities of the future sultan, these activities were incorporating him into the cosmological image that his predecessors had occupied. The sultan retains his image as the protector of the world, and the palace is still a sign of the unification of the macrocosm and the microcosm. In front of the palace stand two banyan trees, Kyai Dewandaru and Kyai Jayadaru, which represent this idea. ${ }^{12}$ These trees had also become significantly involved in the accession rites because not long after the death of HB IX, Kyai Dewandaru crashed to the ground. This ominous sign was being variously interpreted to herald the end of the line, but Mangkubumi casually dismissed it, remarking that the tree

\footnotetext{
${ }^{9}$ KR, February 22 and $28,1989$.

${ }^{10}$ The legend is based on Babad Tanah Jawi, which contains the famous story of the coconut. Ki Ageng Giring had been told that his sons would become kings of Java were he to drink the milk, but his friend Ki Pemanahan drank it by mistake. The drinking of the coconut milk is a hidden code for Ki Pemanahan's adultery with Ki Ageng Giring's wife. The old name for Mount Mahenoko was Mount Lanang (male), which suggests another strand of phallic imagery in the origin myths of Mataram.

11 KR, March 4, 1989.

12 See KPH Brongtodiningrat, The Royal Palace of Yogyakarta (Kraton Museum, 1975), p. 20. This text also became a key reference for interpretation during the accession.
} 
was old. A "shining" (bersinar), two-year cutting, had been secured and would be planted the day after the main accession rites.

Interestingly, students from Gadjah Mada University also participated in the tree episode. The fall of the tree on the North Square was followed by the fall of the banyan outside the Faculty of Social and Political Studies. The students joked that it had been the jodoh (match) of the palace heirloom, but behind their jokes lay a truth: when UGM first began it was located in various parts of the palace, thanks to the sultan's support. The fall of the tree was construed in different ways, but it could be turned to point again to the importance of the palace and its influence in contemporary spheres of Yogya life.

The main accession ritual was to take place on Tuesday, March 7. On Sunday, between rain showers, the rehearsal with carriages and soldiers attracted large crowds. In the Bangsal Sekar Kedaton, the ladies of the court gathered to make apem, the fried rice cakes that are offered before the fasting month and that are also a vital part of the labuhan offerings made to the guardian spirit of the realm. A large labuhan was scheduled to take place after the accession, and the Ngebluk-Jladren and Ngapem ceremonies provided the elements and their assembly, ready for presentation when the time came. By the eve of the accession, these offerings had been arranged in the Bangsal Proboyekso, the kraton's heart and repository of the heirlooms, along with the banyan clipping and other accouterments. Meanwhile, the final touches were being made to the Bangsal Witono where the sultan would be proclaimed. The press reported that fifty-two decorators, including designers, engineers, architects, and interior decorators had been brought in to adorn the hall. Vast quantities of flowers had been provided, often as gifts, to create the effect befitting the occasion: banana stems, orchids, amarils, and jasmine. Ir. Dra. Larasati Suliantoro Sulaiman, in charge of the floral decorations, said that she fasted before starting her important work. The driver of the carriage to be used in the kirab procession was also fasting. Fasting and flowers, facts of Javanese ritual life, but on a massive scale: $150 \mathrm{~kg}$ of jasmine were required for the hall. Even more jasmine had been used for the funeral of HB DX. Flowers are more than important poetic images in high Javanese literature. The powerful and pervasive scent of flowers together with the sonorous and far-reaching sounds of the gamelans represent the intangible but extensive qualities of the king, who is imagined as the center of all this. The night before the accession, the king and his court performed a vigil until midnight with prayers (tuguran and tahlihan), and offerings (sugengan) of pari flowers, panitan coconut, and white sugar. By the following morning, the main palace heirlooms had been positioned in the Bangsal Proboyekso, and everything was ready.

Apart from features on rites and legends, the press showed rather more interest in the events behind the scenes of Javanese rulers and their accessions than is considered appropriate by the purveyors of adiluhung culture (high and noble) and the Javanese way (cara jawa). In some cases, this interest could be turned to support the ideological emphases: the road running through the center of the North Square was proceeding at a rate of $15 \mathrm{~m}^{2} \mathrm{a}$ day, and the cost of labor and material, Rp 8 million (ca. US $\$ 4,500$ ), was being covered by the head of the construction firm so that he would gain merit (ngalap berkah) from the palace. ${ }^{13}$ Extensive restorations of the palace had also been in progress, and reports about the cost of these and the speed at which the work was likely to be completed were reported on regularly.

${ }^{13}$ KR, February 25, 1989. 
Generosity in the name of traditional powers and blessings and expenditure in the name of development and protection of tradition did not raise ideological problems: Javanese idealism does not preclude the possibility of even kings having bills. However, the rites of accession themselves had come to stand as a measure of value of the palace and its future viability, and it had not been classified and imagined as something expensive that would have to be paid for. When comments are occasionally made about the tiny nominal wages (or honorariums) paid to palace retainers, agreement is followed quickly by the qualification that such work is done not for money but for honor (or blessings). The assumption that the accession rites would also proceed with the customary dissimulation of financial nuts and bolts suffered a rude blow when the commercial dimensions of an event so close to the heart of Yogya and its people became known.

There were two strands in the finances of the accession: business sponsorship to pay for the ceremony and film and video documentation that would be sold. The latter allegedly originated from Mangkubumi himself, and in principle there was no objection to filming the event; video recording had become a habitual feature of modern Javanese ritual. Directors were selected at very short notice and saw the work as an honor not for financial gain-as Senior Director Ami Priyono put it. Appropriate offerings were made before the palace was surveyed to select camera positions and plan shots. Extensive coverage was anticipated: reports spoke of thirty-four closed-circuit monitors being installed inside and outside the palace, with nine cameras to serve that system, another three for news, and seven $16 \mathrm{~mm}$ cameras and three Nagra tape recorders to document the event. Smaller crews had already covered the rehearsal and pilgrimages.

The documentation of the accesssion had been contracted to the Matari advertising company by Summa International, of which $\mathrm{HB} X$ is a director and which has strong links with PT Astra, a powerful company with previous palace connections. It was a shocked audience that read one morning that the monopoly on documentation meant that the local state television company (TVRI Yogyakarta) would be unable to broadcast the event live. There were angry mutterings about the "takeover by Jakarta" and criticisms of commercial exploitation. Some said that every time the sultan was photographed, an advertisment for Djarum cigarettes would be in view. This exaggerated reaction was a mark of confusion: handles for making sense of the palace events had been taken away, and the value of the occasion was being sullied by mercantile opportunism. At the same time, the press reported enthusiastically about how full the hotels were, and travel bureaus speculated about how best to incorporate the accession into tourist packages at short notice.

It is unclear how it came about-rumors mentioned a diatribe by a senior Gadjah Mada professor against the monopoly-but it was finally agreed that TVRI should cover the accession with a two-hour live broadcast of the main ritual. The TV and radio crews would comprise 70 people; 250 journalists were also expected and, mindful of the undignified chaos of the media at Mangkunagoro's accession, a press area $40 \mathrm{~m}$ from the throne was set aside, with improved lighting installed to help photographers. Film and video cameras would be forbidden to move from the positions allocated to them. The head of TVRI, meanwhile, made his position clear, "We will try to stand on our own two feet (berdikari). We feel it is unethical for the accession to use sponsors." 14 The TVRI crews would, however, "try to cooperate" with the Matari crews.

${ }^{14} \mathrm{KR}$, March 3, 1989. 
Accurate reports of expenses are not a feature of the Indonesian media; it was claimed the Rp 300 million (about US $\$ 170,000$ ) had been contributed by the sponsors, who included BMW, Mitsubishi, Djarum, and Coca-Cola. Payment from Japan for the broadcasting rights to the accession film and fees for news clips would also enter the budget.

The details of patronage in Javanese culture are discussed elsewhere, but it is pertinent here to note the previous involvement of PT Astra in palace finances long before Mangkubumi's accession, as far back as 1975 when it sponsored a European tour of palace dancers as part of a promotion to raise funds for the UNESCO project to restore the Borobudur temple. ${ }^{15}$ This information (gleaned after the accession) did not come into play during the arguments about the modern image of the sultan and the palace and the means of incorporating the financial facts of life into the concept of the Javanese king. Whatever public knowledge and disapproval of HB IX's business life had existed had been buried with him and forgotten. His son was still within reach of criticism and damaging charges of "ulterior motives" (pamrih), the flaw that unthrones kings and brings down kingdoms.

As much effort as possible was exerted to remove him from the sphere of fallibility, however, and before the accession, a series of comments and accolades from the great, good, and talented of Yogyakarta had been initiated, starting with W. S. Rendra and $R$. Mangungwijaya who said, in different ways, that they hoped HB X would be like his father. Once March 7 had arrived, Kedaulatan Rakyat ran a supplement (bonus) for the accession for three days, providing four extra pages with which to enthuse, celebrate, and reiterate. The postscript to the event, apart from an expensive and elusive video document, was a "Grand Coronation Album" (Album Ageng Jumenengan Dalem Sri Sultan Hamengku Buwono X) in April. Using a format applied to press materials from the funeral of HB IX but on a much more luxurious scale, it sold out immediately, and a second edition was produced, this time with a luxury cover by the artist Sapto Hudoyo. By that stage, business was legitimate and the two faces of the media slants on the accession, seeking grace (ngalap berkah) and cashing in had, mysteriously, become unified.

\section{"A Resplendent, Reverent Event"}

The weather had been rainy but the day of the accession dawned dry, if overcast. The roads into the benteng (fort) had been closed, and crowds flocked to the front of the palace, albeit in smaller numbers than expected. Around the North Square, tall white banners edged in green fluttered in the wind, bearing congratulatory messages. Inside the palace, Mangkubumi was being dressed in the regalia worn by his father at his accession, with shoes said to have belonged to $\mathrm{BH} \mathrm{V}$. Outside, the waiting crowd read stories that dressed him in conventional images handed down orally but today incorporated by the media in a legitimizing strategy to bring modern images of democracy to traditional ideas of kingship.

In Kedaulatan Rakyat, the main story confirmed the title of the new sultan. Whether he should be sultan "in the kingdom of Yogyakarta" or in "the palace of Yogyakarta" had been a moot point. The final choice was the more open "in Yogyakarta," which was not limited to the palace and allowed for the possibility that he might become governor. On the front page too, H. Karkono Partokusumo, director of the Javanologi Panunggal Foundation raised the issue of the sultan's status of Haji (having made the pilgrimage to Mecca) and proposed that the sultan be called "Sultan Haji." Jokers embellished this with the sultan's status as a law

15 Y. Sumandio Hadi, "Seni Tari di Keraton Yogyakarta Pembentukan dan Perkembangannya dalam Masa Pemerintahan Sultan HB IX (1940-87)" (Pasca Sarjana thesis, Gadjah Mada University, 1988), pp. 98-99. 


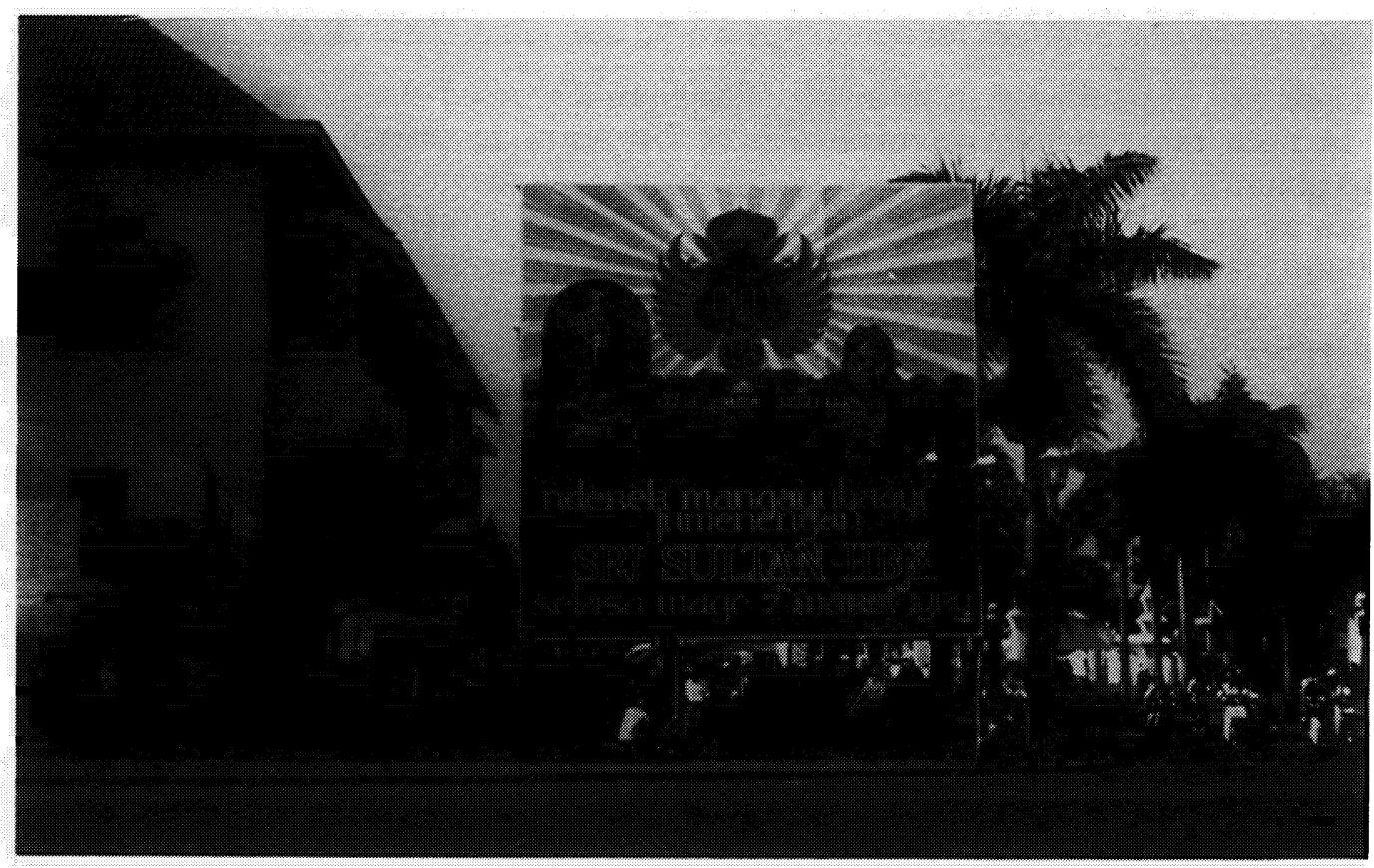

Poster by the Samsoel Group congratulating the sultan on his enthronement.

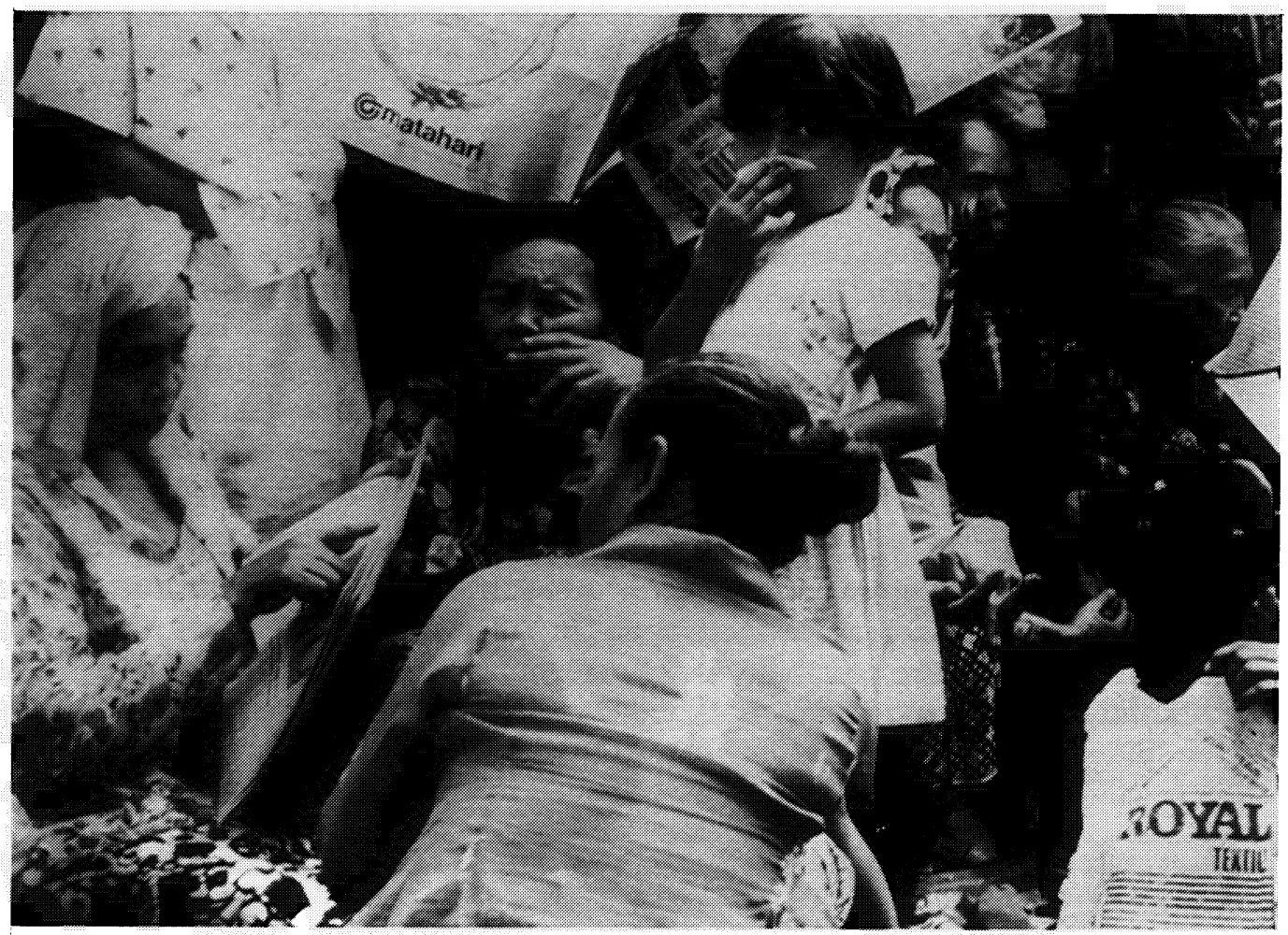

Women read the newspaper before the main coronation ceremony begins. 
graduate giving "Sultan Haji Sarjana Hukum" (Sultan Haji Law Graduate) as a possible nomenclature.

Karkono Partokusumo and Gadjah Mada philosophy lecturer Drs Damardjati Supadjar had been designated official interpreters of the accession. Damardjati kicked off with the claim that the allegorical history written by HB I's son when crown prince, the Serat Suryo Raja was the source for the "origin of the accession strategy" (pangkal strategi jumenengan) and posited the Islamic basis to the accession since HB II. Elsewhere, he claimed people were too afraid to read this sacred text, although Ricklef's account of gaining access to it shows that inconvenience probably is the deterrent. ${ }^{16} \mathrm{He}$ stressed that as long as religious and lahir-batin principles continue, small changes in the accession rite do not matter, "The kraton in Yogya remains one kraton or cultural centre considered strong, constant and resolute in upholding custom through procedure (tatacara) and ceremony (upacara) which have been passed down." In spite of change and outside influence, Yogya is a center for both local and national culture. Here Partokusumo remarks on the appropriateness of the kraton becoming a center for documentation. Irony could be intended or a veiled warning, given the commotion about rights and exclusions to record the accession rites themselves.

Noticeable at this time was a preoccupation with heirlooms. The front page of $K R$ also carried stories about royal daggers (keris) and the Star of Office (Bintang Pusaka). The reports reveal interpretations that apply to the accession as a whole. The star, the report reminded us, was Javanese and made in Yogya, although it was made by the firm of Fontelin and Co. The large $W$ inscribed on it, the report continued, has been claimed by some to stand for "Willem (of Orange)." But the real meaning of the $W$ is that it stands for wangsa (noble); the star was given to HB IV to show his "nobility." This interpretation is revealing for the style of rationalization it describes. Instead of unpacking a story of colonial relations and the meaning of Dutch gifts to the Javanese sultans, the common Javanese strategy of elaborating on signs and emblems to suit the occasion and mood is, understandably, pursued. The star is important because it has adorned the breast of each Yogya sultan since HB IV not because it was made by the Dutch and given to the sultan as a sign of his fealty to them.

Tradition had it that Mangkubumi would wear the Kangjeng Kyai Toyo Tinaban keris until he was enthroned and would then select either K. K. Kopek or K. K. Sengkelat; K. K. Toyo Tinaban would go to BRM Hadikusumo on his promotion to the rank of kraton lurah. However, continued the report, Hadikusumo was not cocok (harmonious) with K. K. Toyo Tinaban so it would be returned to the palace. HB IX had not felt right with either of the traditionally prescribed keris and had always worn K. K. Joko Piturun, the keris given to him by his father. Given the paradoxical elements of $H B$ X's accession, with the emphasis on traditional form and modern circumstances, this data on behavior in keris wearing is revealing and sums up the balance between pragmatism and tradition that characterizes Javanese justificatory strategies. Feelings of rightness, which are culturally valued, can sanction choices that override traditional rules. Or, to put it differently, if HB IX could choose what keris he wore, why can't his son? Given the identification between the attributes of the person and his keris, this newspaper piece can be read as an encoded message that demonstrates that individual choice, such as choosing not to wear the traditional keris, and change can be accommodated into tradition. Mangkubumi, like his father, can choose what is cocok for him, what kind of sultan he will be. Implicit in this reasoning is the idea that the search for "feeling right" will itself be constrained by currently acceptable Javanese orientations.

${ }^{16}$ Ricklefs, Yogyakarta, p. 194 n. 59. 


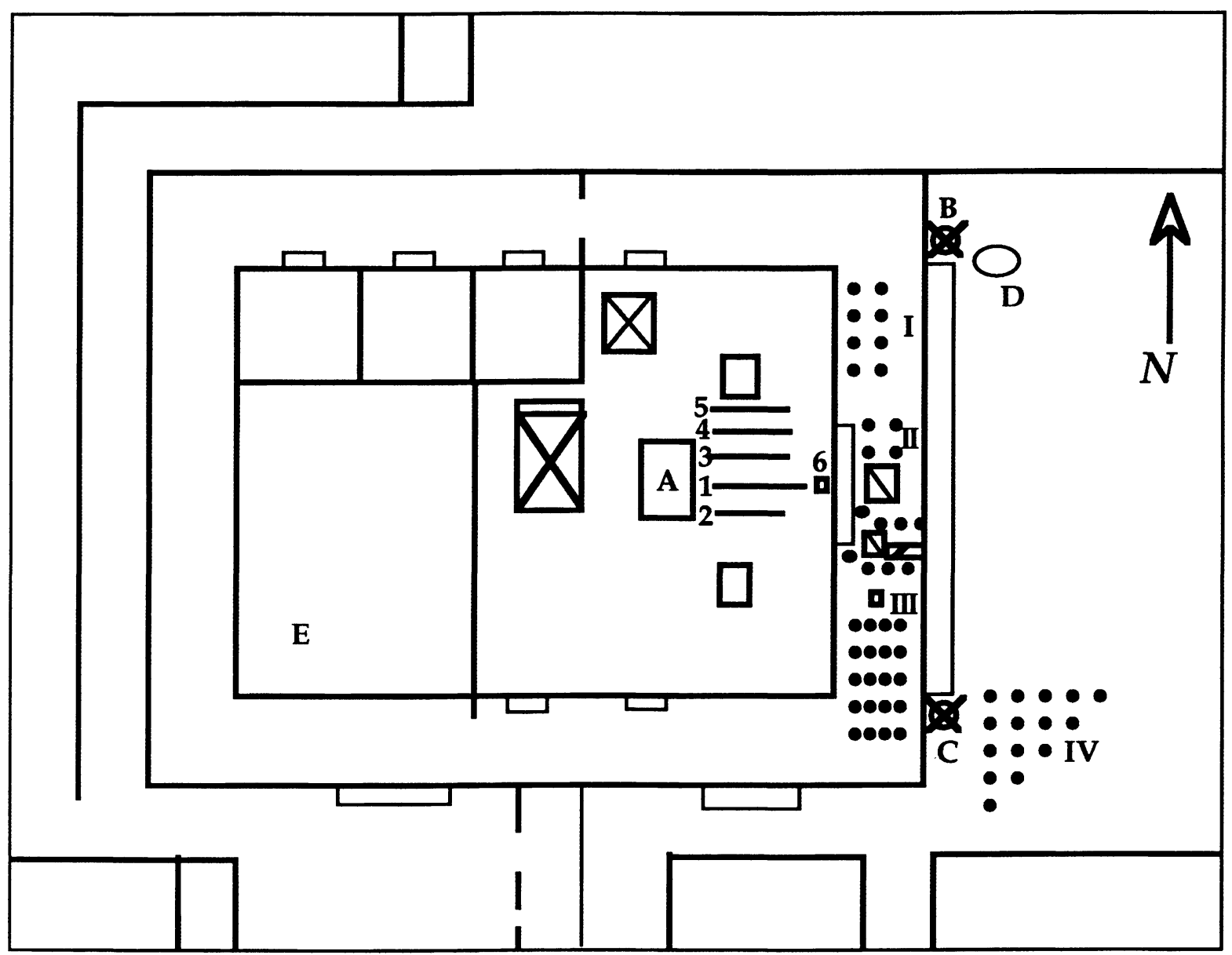

1. K.K.H. Plered

2. K.K.H. Baru Linting

3. K.K.H. Megatruh

4. K.K.H. Godotapan

5. K.K.H. Gadowedono

6. Incense for K.K.H. Plered

I. Manggung

II. Bearers of Royal Accouterments

III. B.R.Ay. Mangkubumi and Ladies

IV. Bupati, Royal Grandchildren, and Spouses
A. Labuhan Offerings
B. Sultan's Golden Parasol
C. Queen's Golden Parasol
D. Young Banyan Tree
E. Place for Sultan's Clothing

Fig. 1. BANGSAL PROBOYEKSO. Adapted from figures in "Pranatan Lampah-Lampah Jumenengipun Kangjeng Gusti Pangeran Haryo Haji Mangkubumi Sarjana Hukum." 
The editorial comment for the day expressed all this in plain terms, emphasizing the longstanding plan of HB DX for his son to become the next sultan and expressing the hope that $\mathrm{HB} X$ would develop the leadership abilities he had already established in his selection "by the people" to lead the provincial assembly of Golongan Karya (GOLKAR) and to represent it at both Representative and Consultative Assemblies (DPR and MPR) as well as heading the local mercantile association (KADINDA).

The four-page "bonus" produced by Kedaulatan Rakyat during the highpoints of the accession rites provided more space for well-wishers to publish messages and material balancing between the old-established nature of the sultanate and the forward-looking character of Mangkubumi. Thus a report on hinted initiations of the future sultan into Javanese mysteries was accompanied by stories about his wage in the kraton ( $R p 30,000$ per month) and his marriage to Tatiek, illustrated with a photograph of the blue-jeaned couple on a bicycle. Two serials running during the accession also showed this Janus-like approach: a history of the Yogya dynasty was balanced by a series of reminiscences by people who knew Mangkubumi as a child, all of which were designed to show his public spiritedness (sifat kemasyarakatan). This serial with its emphasis on Mangkubumi's modern education again demonstrates the amnesiac principle: HB IX had also had a modern western education, but this was repressed to create a specific characteristic of the new sultan, the former sultan having belonged to an earlier age when the Dutch pulled the strings. By this stage, criticisms of Mangkubumi were also repressed: just as death had cleansed HB IX's reputation of negative elements so Mangkubumi's new name would emerge clean of the comments that had clung to Mangkubumi. As ceremony took over from controversy, the amnesiac principle continued to prevail: tradition it seems, depends on specialized forgetfulness, or controlled remembering. The ceremony, constructed with the help of local experts from higher educational institutes, took place inside the palace, and the media provided the means to help the public remember and influenced how.

By 8:00 A.M., the palace guests were seated and the gamelans K. K. Surak and K. K. Kancil Belik were entertaining them. Soldiers had been marching slowly to various positions since 7:30. In the Bangsal Proboyekso, the palace kin and officials had assembled around the heirlooms (see fig. 1), and at 8:30, Mangkubumi emerged to the accompaniment of Lung Gading and Sri Katon played on the gamelons K. K. Sirat Madu and K. K. Madu Kintir and was seated. ${ }^{17}$ At 9:00 A.M., the procession of personnel and heirlooms set off at a slow pace towards the Sitihinggil to take their places for the proclamations (see fig. 2). The procession was in this order:

1. Low-ranking retainers (punokawan) and second-, third-, and fourth-level descendants (wayah, buyut, canggah) of sultans

2. Bearers and the Golden Throne

3. Princely officials and bupati

4. Princes and male relatives

5. Polowijo retainers (dwarfs and albinos)

6. Manggung, young female relatives (wayah, buyut) bearing the royal regalia (upacara) ${ }^{18}$

17 The following details are taken from the kraton booklet of instructions for the accession rites, Pranatan LampahLampah Jumenengipun Kangjeng Gusti Pangeran Haryo Haji Mangkubumi Sarjana Hukum, produced by the committee for the accession. Nomenclature and spelling follows this booklet. Press reports drew information from this source but often confused the order of events and details of rituals.

18 Representing the royal attributes, the regalia include golden images of a goose, deer, cockerel, peacock, snake, handkerchief box, powderbox, and lantern. Brongtodiningrat, Royal Palace, pp. 18-19. 
7. Prince Mangkubumi and his brothers Prabukusumo (GBP Adjudan-Dalem) bearing the Star of Office, and Joyokusumo, with the Golden Parasol unopened

8. Female retainers (keparak) bearing the royal accouterments (ampilan) ${ }^{19}$

9. Princely officials, Bupati Nayoko/Kliwon/Riyo bearing the five palace heirlooms (K. K. Pusoko-Dalem)

10. Religious retainers (Pemethakan)

11. B. R. Ay Mangkubumi with a closed Golden Parasol, royal wives, princesses, wives and widows of princes

12. Nyutra soldiers, the special guard, today enacted by dancers able to sustain the special wide, out-turned "gentle" (impur) walking style

13. Ketanggung and Mantrijero soldiers.

14. Other female kin and retainers not going into the Sitihinggil

Once everyone was in place, for the first time in a Yogya accession sections of the Quran (Al Fatihah and verse 35 of Ali Imron) were read aloud by H. Muammar Zainal Asyikin from the Institute for Higher Quran Education (LPTQ) in Jakarta. The inauguration of the crown prince (Jumenengen Kangjeng Gusti Pangeran Hadipati Hanom [KGPHH]) followed. Hadikusumo, head of the Kawedanan Hageng (KH) Sri Wandowo and a "master of ceremonies" for the accession, invited the guests to stand, and Joyokusumo requested Mangkubumi to take his position. Hadikusumo asked for the proclamation to be read, which was accomplished by Raden Mas (RM) Dinu Satomo. The newly inaugurated KGPHH Hamengku Negoro Sudibyo Rojo Putro Narendro Mataram was seated behind the sela gilang (a dark marble slab), and everyone sat down.

The inauguration of the sultan (Jumenengen-Dalem Noto) followed directly. Hadikusumo again invited the guests to stand, the bearers of the regalia and accouterments took up new positions, and the five heirlooms were unsheathed. Joyokusumo invited the crown prince to stand centrally in front of the throne, and Hadikusumo ordered the reading of the proclamation for the inauguration of Ngarso-Dalem Sampeyan Dalem Ingkang Sinuwun Kangjeng Sultan Hamengku Buwono Senopati Ing Ngalolo Ngabudurakhman Sayidin Panoto Gomo Kalifatullah Ingkang Jumeneng Kaping X Ing Ngayogyakarta Hadiningrat. Monggang and Kodhok Ngorek were played on the gamelans K. K. Guntur Laut and K. K. Kebo Ganggang. Joyokusumo invited the sultan to step up into the Bangsal Manguntur Tangkil in front of the Golden Throne, and the Golden Parasol was unfurled. Prabukusumo was then asked to step forward with the Bintang Pustaka, Star of Office, which GP Poeroeboyo, the senior surviving brother of HB IX, pinned on the sultan's chest. Everyone then sat down. The sultan sat in state on the throne (siniwaka), the quintessential position of the sultan holding the kingdom together in contemplation of the unification of the microcosm and the macrocosm. After the gamelans were quiet, a salvo of three shots was fired by the palace guards, and the sultan rose to give his address (Sabdotomo). After the address, Hadikusumo instructed that the proclamation about the palace emblem (Projo Cinho) should be read. Four more inaugurations followed: Mangkubumi's wife was promoted to Gusti Kangjeng Ratu Hemas (queen); GP Poeroeboyo became Kangjeng Panembahan; Princess Suryowijoyo and Hadikusumo became joint lurah of the palace; and the sultan's five daughters became royal princesses (Gusti Raden Ajeng). The ceremony in the Sitihinggil concluded with a prayer (donga) by the religious retainers.

\footnotetext{
${ }^{19} \mathrm{~K}$. K. Mangunoneng (two swords), Sumbul containing a silver tea set, a urinoir, spitoon, arrow container, peacock fan, chest, shield, and ginondong from the time of $\mathrm{HB} \mathrm{I}$-nine in all.
} 


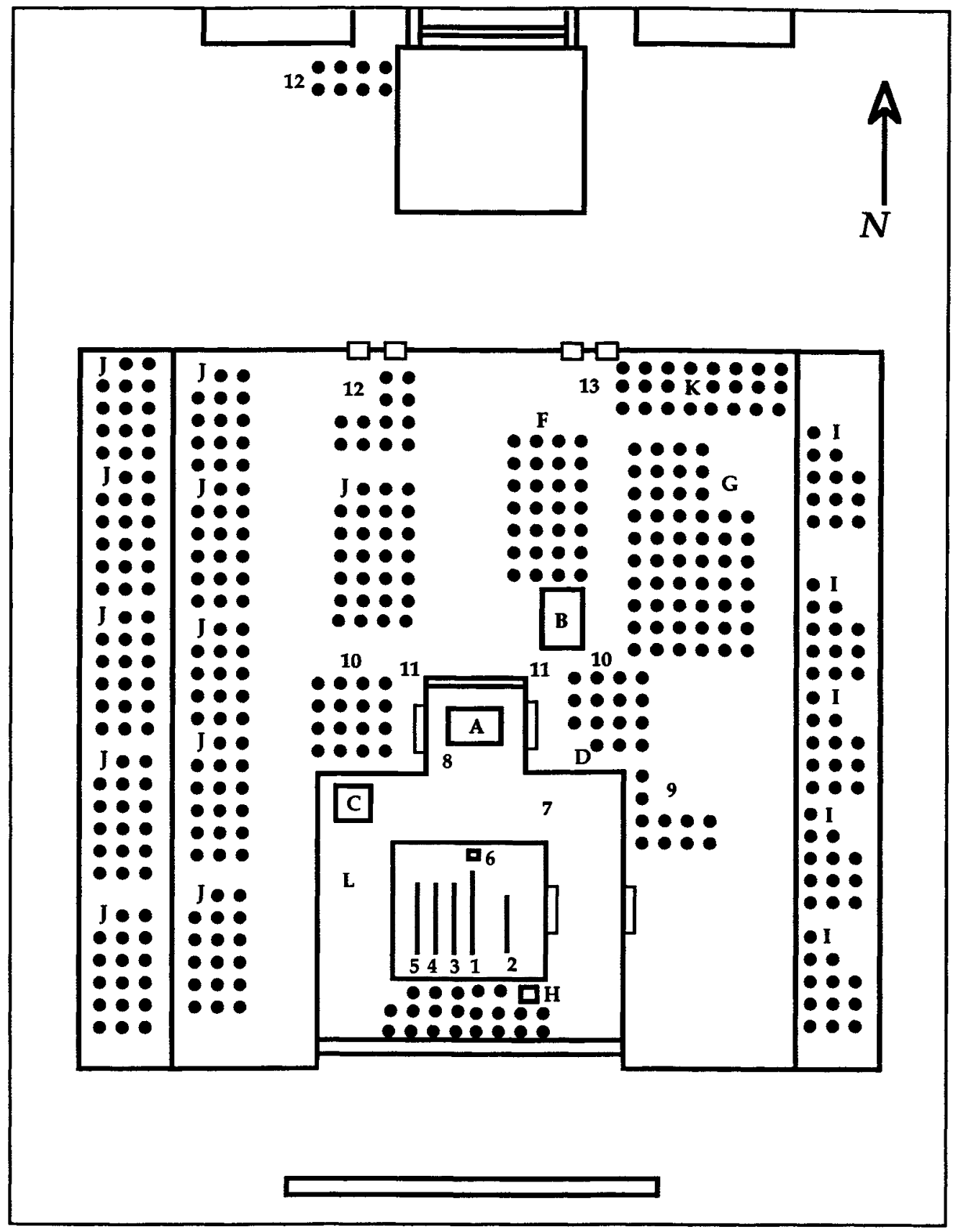
1. K.K.H. Plered
2. K.K.H. Baru Klinting
3. K.K.H. Megatruh
4. K.K.H. Godotapan
5. K.K.H. Godowedono
6. Incense for K.K.H. Plered
7. Royal Accoutrements and Regalia
8. GBPH Prabukusumo and Star of Office
9. Abdi-Dalem Polowijo
10. Abdi-Dalem Prajurit Nyutro
11. Abdi-Dalem Proloto
12. Readers of Prayer, Al Quran, and Abdi-Dalem Pemethakan
13. Microphone

A. Throne of Sultan

B. Seat of Crown Prince

C. Throne of Queen

D. Sultan's Golden Parasol

E. Queen's Golden Parasol

F. Close Male Relatives

G. Princely Officials and Bupati

H. B.R.Ay. Mangkubumi and Ladies

I. Female Bupati, Grandchildren, Spouses, Princely Officials, and Male Bupati

J. Guests

K. The Press

L. Bangsal Manguntur Tangkil

Fig. 2. BANGSAL WITONO, JUMENENG-DALEM NOTO. Adapted from figures in "Pranatan LampahLampah Jumenengipun Kangjeng Gusti Pangeran Haryo Haji Mangkubumi Sarjana Hukum." 
The crowds outside the palace had been able to hear the music, and toward the end of the ceremony, a breeze carried the scent of jasmine from the Sitihinggil. Diversion had come in the endurance and ordeal of an elderly Bugis soldier who had collapsed in the heat. Although the ceremony had been relayed over loudspeakers, the content of the proclamations and the sultan's address had been inaudible. After the prayer, around 10:30 A.M., the sultan and his queen proceeded to the Bangsal Srimanganti to receive the congratulations of their guests. The crowds waited outside to watch the withdrawal of the soldiers and the departure of the VIPs. Inside the palace, after lunch, the final ritual of the day, the pasowanan ngabekten, in which the kin and retainers come to congratulate the sultan, was held in the Bangsal Kencana. After the sultan retired to the tunes Tedak Saking and Sri Kundur and the royal heirlooms, regalia, and accouterments had been returned to their places in the Bangsal Proboyekso, the events of the day were completed.

\section{Interpretations and Tradition by Omission}

The following morning the headline in Kedaulatan Rakyat read as follows: "The coronation in the midst of charismatic splendour: A throne for socio-cultural well being" (Jumenengan dalam kemerlap berkharisma: Tahta bagi kesejahteraan sosial-budaya). The ceremony had, if anything, taken the media by suprise. There had been none of the mayhem of the Mangkunagaran accession nor any taint of commercialism: ethos had transcended economics. Press reports were full of praise for the dignity, beauty, and style of the accession proper and spoke in terms of radiance, charisma, and reverence. Apart from detailed reports of the heirlooms involved and the effect of the television coverage-keeping people at home-the press gave their attention to the new female power in the palace. Elderly retainers who had been present at the accessions of HB VIII and IX remarked not only on the larger scale and elegance of the new accession but on the presence of women, who were not previously invited to the Sitihinggil ceremony. The ramifications of the female order of precedence were spelled out in considerable detail on the front page of $K R$, but the element of most interest was the sultan's address, printed in full in the "bonus."

The address, in Indonesian, was an elegant attempt to establish the coordinates to validate the existence of a sultan within a Republic. Leaning heavily on the catch phrase title of the book dedicated to his father, "Tahta Untuk Rakyat" (A throne for the people), the sultan ratified this objective, saying that his duty to the people was to preserve the values of their race and culture as set down in the Pancasila (state ideology) and the Proclamation of 1945. Using a typical Javanese rhetorical strategy for structuring ideas, he unpacked his name, Hamengku Buwono into a threefold exegesis (suraos) to explain his responsibilities and undertaking. Hamangku is to give more than to receive; hamengku, to protect without discriminating between groups, faiths, and religions; and hamengkoni, that patrimonial leadership in traditional socieites has to be exemplary and to take full responsibility whatever the cost. The kraton, with its "cosmophilosophical basis" had been transformed under HB IX into a "miniature Indonesia within the overall Nusantara culture," and culture is the source of "inspiration, creation, and aspiration" of the people. State principles require that the people should speak and be heard: hamengku is also "to listen." Whereas his father had sworn allegiance to the Dutch government, HB X's message was to the people: "As I inherit the throne and take up this mission, I promise faithfully to secure the throne for the people, for the preservation and well being of the sociocultural life of the people. With such a resolution, the aspiration to make the palace a centre of cultural events and development in the harmonious spirit of adiluhung [high and noble], tradition with the support of every faction will hopefully be achieved. As a member of the succeeding generation, I will not turn back 
[ora mingkuh] from the implementation of the revolutionary ethos of the founder of the palace, Prince Mangkubumi I."20

Most reports over the coming week were based on this masterpiece of condensed contradiction, which is a sign of traditional Javanese realpolitik; on the same day, a peculiar item in the financial section of the paper analyzed the palace as a sociocultural commodity, a means for the people to reflect and evaluate progress by providing an institution that is constant: the future can only be faced if Indonesians strengthen their roots. By this stage, the carping about the sponsors and the filth of lucre had been washed clean by the force of the rhetoric and the skillful management of the accession rite itself, which had given the sultan a positive launch to what would doubtless require a skillful helmsman to steer a course between the past and the future, between the portfolio and the pamrih.

The commentary about the accession continued to display the characteristics already discussed. A certain loss of proportion lead to articles comparing the sultan with the crown prince of Britain and the emperor of Japan; after all, the jumenengen had hardly made the world news, even if Yogya is the center of the world.

Yogya's sphere of influence might be circumscribed, but the events yielded significant truths in the fields of political and philosophical analysis. Kuntowijoyo was reported somewhat confusingly to have stated that the power of the kraton rested on its lack of real political authority-that only by not having actual power could it become more democratic. He proposed that HB X's legitimacy was based not on wahyu (divine grace) but on family consensus. The palace, he continued, did not have the authority to provide welfare for the people. Its role was strictly cultural.

This view ignored the post facto ascriptive quality of wahyu in the legitimizing process and, of course, made no mention of the colonial underpinnings in the kraton up to 1945. The idea of power was treated rather literally. Indeed, commentaries touching on this subject use very narrow definitions of politics. The Muslim intellectual, Dr. Simuh, argued against the syncretism of religion in Java, stating that each prays according to personal creed and that palace Islam is based on Al-Barzani sufism. There has been no Akbar in Java, he added, and the sultan's role is cultural. It is unlikely, he concluded, that the palace will lead a revolution.

Damardjati's perspective was metaphysical. He asked that the accession should be read not as a play (kethoprak) but as cultural momentum, as a philosophical event expressing repentance and a resolution to act better. Given the tendency of palace performers of the senior generations to read such messages into palace genres such as Bedhaya, Golek, and Wayang Wong, Damardjati, perhaps, is taking a Western view of theater as a reduction of reality not as another version of it. Given the themes of conflict, upheaval, and regicide that dominate kethoprak, there is one sense in which it would be risky to see the accession in these terms rather than purely reductive. The risk would be to the established order of the state not to that of the palace itself. In either case, the subtext echoes the two previous ones: culture not politics. Morality, it seems, is of the first order.

Values that are evoked in the name of nobility or highness are not reflections of a feudal system but come from the spirit and are necessary for a nation to achieve quality. The sultan's title expresses a moral role, and it is to be hoped that Yogya can become a prototypic city, effecting a harmonious combination of tradition and modernity. One might remember that the place of Yogya in the Republic is a common topic, especially in view of the number

${ }^{20}$ KR (bonus), March 8, 1989, p. 1. 
of Yogyakartans in positions of influence. What happens in Yogya has significance for Indonesia. As sociologist Umar Kayam put it, 'Yogya's tempo is still Javanese. But Java is no longer Java, and Indonesia isn't quite there yet [belum jadi]. Yogya is an expression of Indonesian culture."21

Damardjati's interpretation of the accession rite was based on what has become a key text for interpreting the palace and its traditions, Brongtodiningrat's pamplet on the meaning of the palace, available in Javanese, Indonesian, and English at the palace souvenir shop. It is the discussion of the Garebeg rituals in which the sultans used to take part that provides a system of references with which to endow the accession with traditional force. The progress of the Garebeg procession through the palace is explicated by an exegesis of names and trees as it moves toward the climax when the sultan sits on the throne, siniwaka, looking north from the Sitihinggil between the two banyan trees on the North Square along Jalan Malioboro to the phallic tugu behind which rises the splendor of Mount Merapi. In this interpretation, it is not the person or the accession that matters but the significance of the path taken and the cosmological completion as the sultan sits on the throne.22

The transfer of interpretation from the Garebegs to the accession is interesting not so much for what it says as what it allows to be ignored. The emphasis is on the image of the sultan in what he would perhaps term a "cosmophilosophical" union. Other significant elements, such as the metaphysical mapping inherent in the structure of the palace, are likewise borrowed from one version of the kraton's "meaning." The use of Brongtodiningrat's text, like the focus on the sultan's speech, serves to detract from the absence of an accession tradition that serves the metaphysical concept of the sultan as holder of the world in his lap. Indeed, the glosses on the name Hamengku Buwana in the speech shifted the sense from cosmology to accountability of a more pragmatic and accessible nature, even if both share rhetoric as their motive.

I was suprised, having worked with palace dance for a long time, at the absence of any performance in the ceremonial except four folk dances from the kabupaten to entertain guests while the sultan made his circuit around the palace. ${ }^{23}$ And yet of all the attributes and prerogatives of the king and his special cosmological status, dancing has been a distinctive feature of Javanese palace culture and a part of accessions. In Surakarta, Bedhaya Ketawang is performed at the accession of the Susuhunan and on each anniversary (tingalan dalem jumenengan). In the sultan's palace in Yogya, Bedhaya Semang was regarded as the equivalent to the Ketawang until it ceased to be performed late in HB VII's reign. Evidence suggests that male dancers in female dress used to perform Bedhaya Semang at the accessions of sultans and the anniversaries. ${ }^{24}$ It has been argued that wayang wong (dance drama) supplanted Bedhaya as state ritual at the foundation of Yogya, with the first performance occurring between 1758 and 1760 to commemorate the accession of HB I. ${ }^{25}$ There is, however, no evidence that it replaced Bedhaya as the approved accession genre. A Dutch account of the

\footnotetext{
21 Tempo, March 18, 1989, p. 57.

22 See F. Hughes-Freeland, "The Search for Sense: Dance in Yogyakarta" (Ph.D. diss., London University, 1986).

23 See also, Suryanto Sastroatmodjo, "Rahadyan Jumeneng Ring Risang Jumenengan," Citra Yogya 8 (1989): 6-17.

24 See Van Moens, Platenalbums (1933-1937), vol. 29, plates 37-43 and pp. 27-28 of the Latinized transcript in Sonobudoyo Museum, Yogya. Further evidence suggests that Bedhaya Pusaka Sumbreg was performed at the accessions of HB III and HB IV (Serat Kandha Bedhaya Srimpi, cat. no. BS 24 Widyabudaya Library, Yogya Kraton, A. D. 1854).

25 Soedarsono, Wayang Wong: The State Ritual Dance Drama in the Court of Yogyakarta (Yogyakarta: Gadjah Mada University Press, 1984), pp. 94-95.
} 


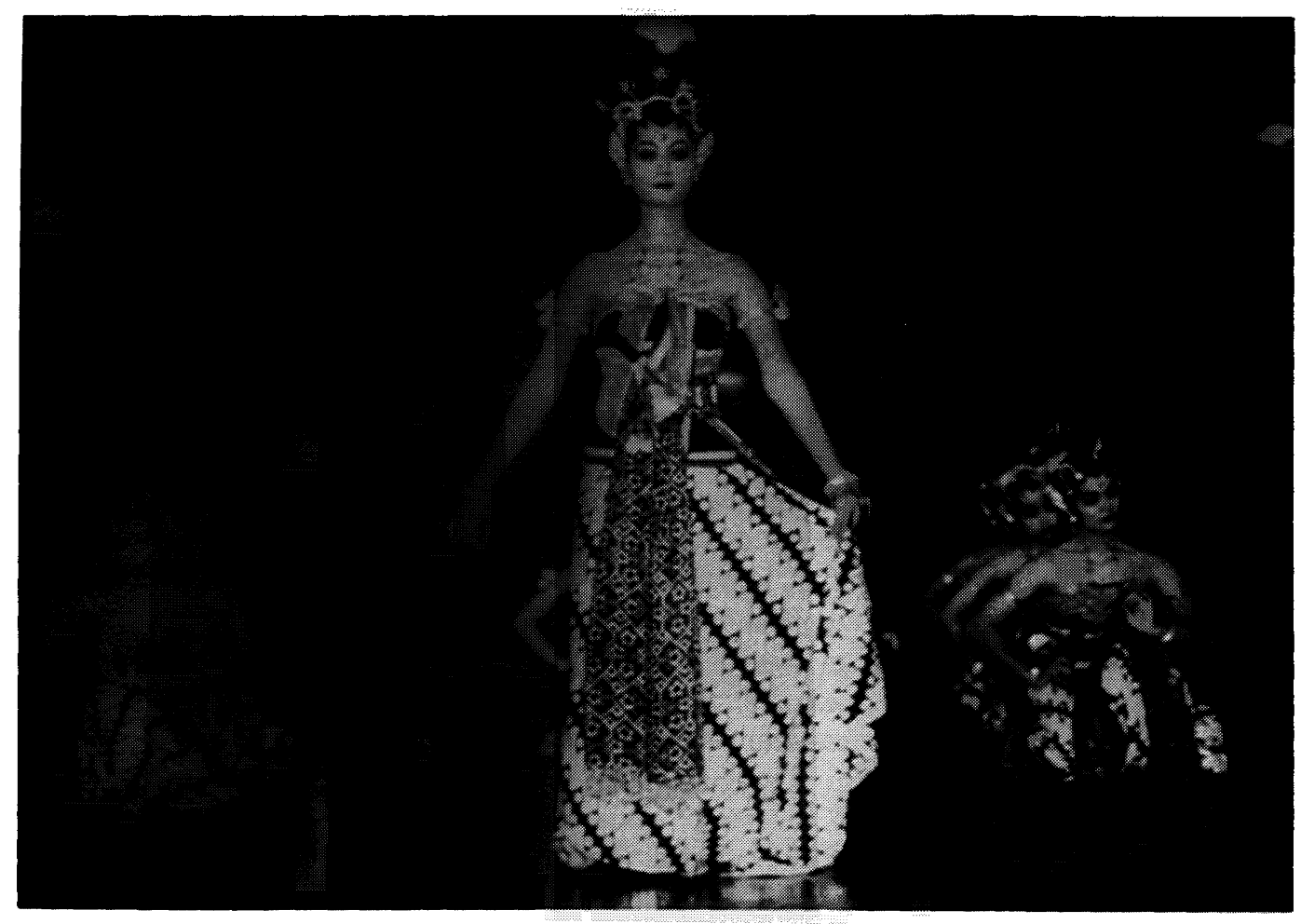

\section{Representation of the sultan after he has received the Star of Office in Bedhaya Herjuno} Wiwoho, performed by members of the Siswa Among Beksa Foundation, July 1989.

accession of HB VIII mentions a performance of a wayang wong fragment at the home of the Resident four days after the accession proper, but there is no mention of a Bedhaya; ${ }^{26}$ perhaps there had been a private reception in the kraton later to which the palace women were also invited, and the dance may have taken place then. For the accession of HB DX a new Bedhaya, Jatiwarna, was created, and is remembered as having been performed during the reception in the evening of the accession day after the kirab.

Although the new sultan is not noted for his enthusiasm for traditional performance, it is unlikely that he would risk asking for the exclusion of so potent a sign of traditional kingship. In any event, he was unable to avoid the presentation of a Bedhaya to him. In July 1989 , at the annual concert to celebrate the founding of their organization, the Siswa Among Beksa dance foundation presented the Accession Bedhaya (renamed Bedhaya Herjuno Wiwoho to make it clear whose accession it was for). Choreographed by B. R. Ay. Yudonegoro, former bedhaya and acclaimed teacher of palace-style classical Yogyakartan dance, the Bedhaya represented the preparations of the sultan for the accession, the moment when the sultan is inaugurated, and the subsequent reception. The 1.5-hour dance was accompanied by lyrics by R. M. Dinu Satomo, which described in elegantly concentrated form the main elements of the accession. Bu Yudonegoro said that she had based the dance on the old (kina) Bedhaya Durma, which she thought dated from HB II's accession. The Durma melody, which gave the old dance its name, was used for the first main section of her Bedhaya and

${ }^{26}$ M.N.D.d. W.v.W., "De Feesten, ter Gelegenheid van de Troonsbestijging van den Tegenwoordigen Sultan van Djocjakarta," Indië 9 (8): 126-32; supplementary photographs may be found on pp. 122-25. There are no details of who the performers were or what the lakon was. 
used a small number of instruments (kemanak, rebab, gambang, gender, kenong, and gong). At the point when the dancer portrayed the sultan newly appointed, the accompaniment took up the melody Monggang that had played at that point in the ritual itself. ${ }^{27}$

After the performance, the sultan was presented with the text of the dance as a sign that it was his prerogative (kagungan dalem) along with a video recording (made two days' earlier). He responded with a speech in Indonesian praising the group's work and their future contributions to the development and preservation of Yogya's culture. The sultan was treated to another accession Bedhaya, Gathutkaca Wiwoho by the Mardawa Budaya foundation on the occasion of his birthday, in the Pagelaran in December 1989.

\section{Perambulation and Visitation}

The inauguration was one rite among many: the pilgrimages preceding the accession proper were reiterated by a number of movements in space on the days following the accession. Scheduled for Wednesday, but spread over two days owing to organizational difficulties, four sets of offerings comprising the labuhan rituals were also integral to the accession's traditional significance. The offerings themselves had been laid out formally throughout the accession proper, and their distribution was considered vital to the fulfillment of requirements. Normally done competely once every eight years, offerings were given to the four protective spirits of the realm: Kyai Sapujagat on Mount Merapi to the north; Kangjeng Ratu Kidul at Parangkusumo on the south coast; Eyang Lawu at Argodalem on Mount Lawu to the east; and an unnamed recipient at the source of the Solo river at Dlepih, Wonogiri. ${ }^{28}$ While the labuhan offerings were being dispatched, Prince Hadiwinoto was planting the new banyan cutting in the North Square. A small number of elderly people were clustered around the walled site, where they had spent the night in meditation, hoping to gain blessings (ngalap berkah).

The main event to come, however, was the Wiyos-Dalem Kirab, the customary circumambulation of the city by the newly enthroned sultan. The rarity of this event provided part of its appeal. In the neighboring court city of Surakarta, kirab happens on every Javanese new year's eve, but the last time Yogya had experienced a major kirab had been on HB IX's accession, when the sultan and Governor Lucien Adam had driven around the palace walls the afternoon after the proclamation of the new sultan. ${ }^{29}$ The royal progress around the 4.5 $\mathrm{km}$ boundary of the palace enclave was much more than this in 1989. It became a carnival. The procession was headed by the religious retainers, then palace guards, horses carrying heirlooms, princes on horseback, and the Golden Coach itself, carved with dragons and adorned with garlands of jasmine and floral rosettes, carrying the sultan and Hadikusumo. More carriages were followed by over fifty local groups: drum bands from schools and colleges, male drum bands, female drum bands, mixed drum bands, drum bands with majorettes in miniskirts and long white boots, and drum bands of Muslim girls in jilbabs (head coverings) and long skirts. Palace guards, veterans, Boy Scouts and Girl Scouts, drama groups, and pencak silat (martial arts) groups-the procession was still marching at dusk,

27 Interviews with R. R. Ay. Yodonegoro July-December 1989. My thanks go to RM Dinu Satomo for the text of the dance and a copy of the video.

${ }^{28}$ Further details of labuhan may be found in Tirtakoesoema, "De Verjaring van den Verheffings dag van Z. H. den Sultan van Jogjakarta (Tingalan Pandjenengan)," Djawa 13 (1933): 372-88; and Hughes-Freeland, "Search for Sense," chap. 5 .

29 There had been another major encirclement in 1948 when the sultan carried the heirloom flag K. K. Tunggul Wulung in an attempt to counter a plague epidemic. See Selosoemardjan, Social Changes in Jogjakarta (Ithaca, N.Y.: Cornell University Press, 1962). 
although the sultan had already reached the palace and, as rumor had it later, despite the encumbrance of his black velvet costume had run right through the palace to the sanctuary of his own quarters.

The turnout for the kirab was massive. Before the procession left the palace at 2:00 P.M, the North Square and surrounding roads were solid with spectators. The city had been closed to traffic. Whereas the procession the previous day had been hidden from the public, today's was fully open, and over one million people were determined to see their new sul$\tan$ without the mediation of the television set or the press. The kirab set out from the Pagelaran, crossed the North Square northward, and turned east, following the roads around the outside of the fortification in a clockwise direction. Invited guests sat in the Pagelaran for the duration of the circuit. The mood of the crowds was festive, occasionally verging on hysteria, and a number of people fainted in the crush. After a three-hour wait near the end of the circuit, the first sound was the roar of police sirens. Then the clatter of hooves commingled with the sounds of pipes, gongs, and drums until the Golden Carriage passed by. Everyone had been ordered to stand by the police and security men, and although everyone waved, a strange silence surrounded the carriage itself, in which the wearied sultan waved a white-gloved hand to the jubilant populace. This spectacle erased any remaining scepticism about the proceedings in Yogya over past weeks; delight was unanimous, and in spite of the mixed sounds, the drum bands, xylophones, sidedrums, and kentongan (bamboo slit gongs) hot on the trail of the earlier marches, the mystique of the sultan had survived the conversion of kirab into a carnival. Despite the television coverage and the film maker Chairul Umam directing a scene from "Malioboro" against the kirab, the moment when the sultan passed by in the Golden Coach had held a special feeling.

It was not the modern but the mystical dimension of the sultan that was brought out by the stories on the kirab. There had been a certain amount of discussion in advance about the fact that the queen would not ride in the carriage with her husband. During the circuit, she sat with her guests in the Pagelaran, dressed in a long golden-yellow kebaya. In his carriage, the sultan sat against the right-hand side, and his brother faced him, sitting cross-legged.

What was the reason for this arrangement? A line of explanation was derived from an adventure that befell Prince Prabukusumo, who had been riding ahead of the carriage. $\mathrm{He}$ claimed to have seen a beautiful woman dressed in greenish yellow enter the carriage. Later, as the procession came past the post office, his horse reared and he was thrown. Strangely, he was unhurt, "I felt as if I had been caught in someone's lap." ${ }^{30}$ His clothing was slightly torn, and his keris had come out of its sheath. This he took for a sign that the keris was not appropriate for that occasion, and he gave it to someone for safekeeping. After that, the horse behaved perfectly. The prince added that he had earlier seen a woman's form between the two banyans on the North Square and that the horse had become skittish there as well. Joyokusumo said that he had felt "something" in the carriage, and HB X just smiled mysteriously. The Sunday papers carried a close-up photograph of the sultan in the carriage shrouded in what was termed a "mysterious mist." To photographers, the blur was more a "technical error," but the speculation by then had begun to congeal into legend.

These odd hints and allusions could mean only one thing: the sultan had been sitting to the right of the carriage so that Kangjeng Ratu Kidul, the sea goddess, could sit on his left. It was she who Prabukusumo saw climbing into the carriage. The figure of a sea goddess with a capricious temperament is found not only in Java but in many regions of Southeast Asia, but what matters here is that Kangjeng Ratu Kidul, Queen of the South Sea, is believed to act

30 "GBPH Prabukusumo Lihat Bayangan Wanita Cantik Masuk Kareta Garuda Yekso," KR, March 10, 1989. 
as consort to the kings of Java. To her are made the offerings each year at Parangkusumo and to her is attributed the origin of the sacred Bedhaya Ketawang, which describes her amorous encounter with the founding father of Mataram, Senopati, or his grandson Sultan Agung. Ratu Kidul is believed to attend the annual performances of Bedhaya Ketawang at the palace of the Susuhunan in Surakarta. In Yogya, the Bedhaya Semang, also offered to her, ceased to be performed around 1914, but the myth is still powerful. Before he died, HB IX claimed to have seen her and said that he used to address her as Grandmother (Eyang), although she appears as a young girl when the moon is new. ${ }^{31}$

Despite a sophisticated understanding of her role in legitimizing strategies to strengthen the Javanese kingdoms, she is still treated literally, as the reaction to the kirab shows. There was difficulty with the status of the legend for $\mathrm{HB} X$, who had taken a strong stand about only having one wife. If this was to be the case, what about Ratu Kidul? The Queen, said some, had been left behind to let her husband be joined by his spirit wife. Local historians countered that the sultan used to ride with the Dutch governor on his left; no one explained why the present governor of of Yogya had not been invited to take his place. The matter was even taken up by the national weekly, Tempo, and the sultan was asked about Kangjeng Ratu Kidul. His reply was ambiguous: "How you take it is up to you. For my part, there's no need for everyone to know what I experienced. I don't have to tell everyone things like that." 32 Perhaps the best comment on the conundrum was the remark made by one of the palace widows, an aunt to the sultan, who drily observed that the sultan was sitting to the right to make space for where the Dutch governor would have been-and Kangjeng Ratu Kidul sat on his lap.

Although the episode was treated with a pinch of skepticism, the stories about the kirab led to some criticism of $\mathrm{HB}$ X; it was said that as a haji, he should have no truck with such notions. Given the track record of the palace in allowing different religious elements to coexist, it will be interesting to see if $\mathrm{HB} \mathrm{X}^{\prime} \mathrm{s}$ higher Islamic profile will give rise to new interpretations. In one view, the Ratu Kidul story signifies the reception of Allah's power by the first king of Mataram. Another version reads Ratu Kidul as a sign of hakekat or certainty, the third step in the four-fold process of gaining knowledge ( $m a^{\prime}$ rifat). Whatever the case, it is clear that HB X intends to be seen at Friday prayers: his intention to visit the Big Mosque on Kliwon Friday and the different provincial regions on the other four regularly was reported in the press after the kirab at the same time as the stories of Ratu Kidul's visitation began. It is also possible, thinking back to the points raised about the absence of dance at the accession rite, that the association of Bedhaya with Ratu Kidul might have been the reason it was omitted during the rite of accession in the palace.

For the sultan and his family, the kirab was not the end of the ritual. Two days later, four brothers completed the marriage rites that had started by the open coffin of their father five months previously. Once the formal ceremonies were over, a small selamatan (jenang sungsum) was given by the committee of the accession to finalize and give thanks for the well being of the work.

\footnotetext{
31 Tahta Untuk Rakyat, p. 103. To my knowledge, Kangjeng Ratu Kidul's role as consort still carries connubial overtones in Yogya despite being addressed as "Grandmother" by the sultan.

32 Tempo, March 18, 1989, p. 73. A good palace source, unnamed because the comment was made unofficially, suggested that the "political" dimension of the Ratu Kidul engima was problematic enough to prevent attempts to revive Bedhaya Semang in the future after failure in 1972. For political here, one might read "religious," perhaps?
} 
Aside from the interplay of tradition and modernity in the press reporting, the behavior of the sultan himself during the rituals of which he was the focus merits some comment, for there are signs that he is reluctant to play the game. First, he is clearly constrained by the forms and styles of tradition. Yogya was astounded when he was about to read his speech after he had received the Star of Office. Instead of having the text presented to him on a tray by a kneeling female retainer as is customary, he simply pulled out a piece of white paper from his jacket front, which he unrolled and read-in Indonesian. Within the palace, unprecedented informality is putting an end to the sembah (formal salutation of joined palms), and the sultan shakes hands, causing a comical sequence of sembah-handshake-sembah by the other person. How long this continues will index how deeply ingrained are the ideas about the sultan's special status.

Although he dressed in old costumes for the accession and was transformed in status by the rites of passage, the sultan remains a "biznizman," and questions about his political and religious alignments have not been purged by his accession. Kuntowijoyo's assertions about the nonpolitical role of the kraton have not been confirmed. A political work by HB X has already been published ${ }^{33}$ (Kerangka dan Konsepsi Politik Indonesia: Sebuah Tinjauan dan Analisa Perkembangan Politik Nasional Indonesia), and he is taking a reformist approach to kraton affairs; three committees dealing with political, cultural, and social welfare programes have already been set up. This indicates that a second reluctance is clearly at work: the reluctance to espouse the categorical division between culture and politics that the rhetoric of media reports on the accession appeared to be setting in place. Although the accession was provided with frames of reference by the media, with the traditional as ideologically noble (as opposed to feudal), and as modern because democratic (as opposed to feudal), the role that $\mathrm{HB} X$ finds himself in given his inheritance, his own corporate style, and assiduous Islam, falls between the position of the bureaucrat and the legislator, ${ }^{34}$ and his management of the contradictions of his present role will reveal Indonesian developmental structures.

From another angle, the role of the media in communicating the palace rites proved in this instance how easy it is to transform charisma into glamor or the sacred into celebrity. Television is a leveller, and heads of state, politicians, and characters from soap operas can easily partake of each other's attributes: life and kethoprak maybe do become confused in the West as well as in Indonesia. HB IX had been buried as a hero, but the media turned HB X into a star: comparisons between him and the film actor Deddy Mizwar were more than skin deep. ${ }^{35}$

It could be argued that the Weberian distinction between charismatic and bureaucratic authority has become complicated by the celebrity factor and that metaphors describing systems and structures of power need reexamination. The concept of "theater state" avoids the recognition of the published and broadcast media's power to create sustainable images to hold the imagination. What was striking about the interviews with the sultan after the accession in newspapers and on television was how effective they were. Statements by $\mathrm{HB} X$ to the effect that his favorite foods are tempe gembus (a local specialty made of soy bean

${ }^{33}$ KGPH. H. Mangkubumi, SH. Kerangka dan Konsepsi Politik Indonesia: Sebuah Tinjauan dan Analisa Perkembangan Politik Nasional Indonesia (Yogyakarta: PT Mitra Gama Widya, 1989).

${ }^{34}$ D. K. Emerson, Indonesia's Elite: Political Culture and Cultural Politics (Ithaca, N.Y.: Cornell University Press, 1976).

35 See R. Schickel, Intimate Strangers: The Cult of Celebrity (New York: Doubleday, 1986). One wonders whether TVRI will ever broadcast the MPRD and DPRD, following the example set by the BBC recently, which has given a whole new sense to "political theater." 
cake), and cassava leaves, very much foods of the rakyat, the people, made people think that he was just like them, regardless of his birth, position, and wealth. For a while, the protector of the universe became a wong cilik, sharing tastes with the simplest kampung-dweller.

For the rest of the population, the television broadcasts and media hype persisted beyond the kirab, and reports of the sultan's scores in football matches, his kraton receptions, and his many excursions within and beyond the province in the name of duty assailed everyone daily. A new word was in vogue: antusias, meaning "the enthusiasm of the public for the new sultan." As everyone watched another repeat of the accession highlights the day after the kirab, which happened to be Nyepi and a national holiday, a fellow viewer's chance remark seemed to sum it all up: "I feel so glad," he said, "Yogya's culture is now fully restored." 